\title{
Effects of Human Resource Investment on Economic Sustainability of Nigerian Real Estate Industry
}

\author{
Olajide Idowu OKUNBANJ0 ${ }^{\star}$, Lookman Olaseni AJETUNMOBI ${ }^{\star \star}$, Adesina Saliu YUSUFF ${ }^{\star \star \star}$
}

\begin{tabular}{l}
\hline \multicolumn{1}{c}{ A R T I C L E I N F O } \\
\hline Article history: \\
Accepted April 2020 \\
Available online May 2020 \\
\hline JEL Classification \\
R30, 015 \\
Keywords: \\
Economic Sustainability, Human \\
Resource Investment, Return on \\
Asset, Revenue Generation
\end{tabular}

\begin{abstract}
A B S T R A C T
The sustainability of real estate industry in Nigeria has become a challenge to the stakeholders of the industry since the arrival of globalization and this has resulted to the industry low contributions to Nigeria economic growth. Therefore, this research study investigated effects of human resource investment on economic sustainability of real estate industry in Nigeria. The study adopted ex-factor research design data collection and data were collected from the annual reports of Arbico Plc. The statistical techniques adopted were descriptive statistics with regression analysis. The findings revealed that investment in human resource of Arbico Plc has a positive and significant contribution to the firm's economic sustainability. It was put forward that that Arbico Plc should continue to invest more on the human resource via training the employees. Also, regulatory authority on financial reporting in Nigeria should mandate all listed firms in the real estate industry to report employee training cost in their yearly annual reports.
\end{abstract}

(C) 2020 EAI. All rights reserved.

\section{Introduction}

The success of every organization is a function of several factors which human resource is part of. Organisation human resources are also referred to as the employees and they are means which organisations policies and strategies are implemented or executed. It could be said that organizations cannot exist without individuals working in line with the purpose of establishing the organisations. Thus, employees as the human resources are the bloodlife of every organization and attention needs to be given to them by the management. Sampson, Ibeh and Emerole (2016) posited that the achievement of an organisation is a function of the human resources efficiency and effectiveness. The role play by organisational human resources has made them to be regarded as most prized assets in organisations. Human resources possess the skills, knowledge and experiences that can result in development as well as transformation of an organisation. Human resource utilized others organizational resources in actualizing the goals and objectives of an organisation. Due to this importance of human resource, Fawowe (2018) stated that technology is not a challenge to today's organisation, but the art of human and humane-management has become a continuous challenge for executives in the 21st century. This has made organisations to adopt several practices in order to develop the human resources which investment in the human resource has been identified.

Investing in organisations human resource enables the organizations to achieve their goals and objectives. It will make the human resource to be flexible in moving with the dynamic business environment in a developing country like Nigeria. Onwumelu and Dialoke (2018) pointed that human resource investment could induce an employee to stay in an organization for a long period especially if such employee possesses unique talent which is helping the organization to perform well.

One of the means of achieving organizational objectives and goals is the sustainability of an organization. Organizational sustainability has been grouped into three components which are environmental, social as well as economic. The pivotal point of this present research study is on economic sustainability that helps organisations to attain its future goals or objectives. Economic sustainability enables an organization to measure its performance for a given period. It is more vital for the organisation and it ensures its survival and growth amidst the turbulent competitive environment (Sulaeman, Tisnawatisule, Hilmiana, \& Cahyandito 2018). According to Ussahawanitchakit (2017), economic sustainability is the means which an organization can safeguard and sustain its human and material resources.

Every industry in an economy contributes its quota to the growth of the economy. It has been identified by studies that real estate industry in Nigeria contributes poorly to Nigerian economy compared with other industries such as banking, insurance, food and beverages industries among others (Iheme \& 
Chiagorom, 2018; Agundu, Okwandu \& Mba 2015; Aniekwu, Anthony \& Onifade. 2014). Aniekwu et al. (2014) posited that the poor contribution of the industry is as results of ineffective use of the resources available to the construction firms. Relatively, Iheme and Chiagorom (2018) pointed that lack of skilled human resource is part of the challenges in the industry. According to Agundu et al. (2015), real estate industry in Nigeria is characterized by shortage of well-trained indigenous employees to manage and execute construction projects. This has resulted to poor execution of quality project and frequent delay (Tunji-Olayeni, Mosaku, Fagbenle \& Omuh 2017; Tunji-Olayeni, Lawal \& Amusan, 2012). It has been asserted by previous studies that inappropriate human resource managerial practices affect how real estate firms are sustained economically (Olajide \& Okunbanjo, 2018; Mbah et al. 2018). It could be that the firms in the real estate industry are experiencing shortage of skilled human resource due to the inappropriate investment plan(s)(via training and development) which is reflecting on the industry performance. Thus, this assumption is needed to be clarified.

Based on the aforementioned, the study is to examine effects of human resource investment on economic sustainability of real estate industry in Nigeria. Other objectives are to:

i. ascertain the effect of human resource investment (training and development expenses) on revenue generation;

ii. examine the effect of human resource investment (training and development expenses) on return on asset $(\mathrm{ROA})$

\section{Literature review}

\subsection{Conceptual Clarifications}

\subsubsection{Human Resource Investment}

Human resource consists the values, attitudes, and habits that are displayed in an organisation and the leadership that motivates people to display their potential in the organization (Tarus \& Sitienei, 2015). Hashima, Osmanb, and Alhabshic (2015) expressed human resource as the unification of genetic inheritance, attitude, education and people experience in their life and business. According to Baron (2011); Bontis, (2001), human resource is defined as a combination of the following four factors: genetic inheritance; education; experience; and attitudes about life and business. Hines (2000) defined it as the combined knowledge, skills, innovativeness and ability of the organisation's individual employees to meet the task at hand. According to Olajide (2019), human resource deals with the human knowledge and its experience, which is based on other elements and which will influence a firm's value by affecting the other elements. Thus, this study sees human resource as the skills, knowledge and experience of an employee shared with the organization in order to add value.

Human resource investment is the commitment of financial resources of an organization on the employees in order to enhance the productivity of the employees. According to Muna (2012), human resource investment entails workforce plan in selecting, hiring of individuals as employees in an organization and organizing training and development programs. Training and development involves organised process which employees of an organisation learn knowledge or skills for a particular task (Dabale, Jagero \& Nyauchi, 2014). The focus of this paper is on the financial expenses incurred in training and developing the human resource. Thus, the study sees human resource investment as the financial commitment of organizations to train and develop the employees' to acquire more skills, knowledge as well as experiences that will add value to the organisation.

\subsubsection{Economic Sustainability}

Economic sustainability involves making sure the business makes a profit (Zahan \& Sultana, 2019). Economic sustainability refers to business practices that respond to market demands by providing goods and services efficiently and profitability (Wan, Abdullah \& Ibrahim 2018). Thus, the study sees economic sustainability as profit generation of an organization over a period of time. The study employed revenue generation and return on assets as the components of economic sustainability.

Olajide (2015) defined revenue as the annual income which an organisation receives from its activities. Fayemi (2001) defined revenue as incomes generated from different activities of the organization for a period. Revenue comprises amounts received from all business activities and transaction which an organization engages in. Return on assets (ROA) indicates the ability of the firm to produce accounting based revenues in excess of actual expenses form a given portfolio of assets (Cho, Chung \& Young, 2019) and provide insights into the ability of management to perform well with the given resources (Dharmadasa, Gamage \& Herath, 2014). It enlightens stakeholders on the efficiency and effectiveness of the management in utilizing the resources of an organisation.

Gives an idea as to how efficient management is at using its assets to generate earnings, that is, it measures efficiency of the business in using its assets to generate net income. 


\section{Human Resource Investment and Economic Sustainability}

Onwumelu and Dialoke (2018) investigated how development of employees has contributed to the performance of employees. The study adopted primary data through administered questionnaire to collect data from the respondents. The chi-square results indicated that training has positive impact on the performance of oil workers. Muna (2012) used regression analysis to find that training and development has positive effect on overall performance banks in Jordan using secondary data. The studies of Olajide and Okunbanjo (2018); Ekundayo and Odhigu (2016); Okunbanjo (2016) among others revealed that training as an element of human capital investment has significant effect on organizational performance. Afrah (2016); Ojokuku and Sajuigbe (2015); Sowunmi, Eleyowo, Salako and Oketokun (2015) indicated that human capital development enhanced employee performance in Malaysia and Nigeria respectively.

Dawodu, Akintunde and Olulana (2018) focused on food and beverages in Nigeria to demonstrate the relationship between human capital development and organizational performance. It was found that positive and significant association occurred between the performance of food and beverages firms and development of human capital. Sampson, Ibeh and Emerole (2016) investigated effect of human capital development programmes and employees performance in the Nigerian public sector. The study used logistic regression to assert that human capital development programmes are significantly related to the performance of employees. Similarly, Ajisafe, Orifa, and Balogun (2015), Mba and Tonye (2015) reported progressive impact of human resource management practices on performance of firms.

\section{Gap in the Literature}

Inspite of numerous studies relating to development of human resource, there is still very little evidence in real estate industry. Most of the studies reviewed focused on banking industry, food and beverages industry, insurance industry, small and medium enterprise etc (Dawodu et al 2018; Olajide \& Okunbanjo, 2018; Tunji-Olayeni et al 2017; Okunbanjo 2016; Afrah 2016; Ajisafe et al 2015; Mbah \& Tonye, 2015 etc). Moreso, most of these studies reviewed employed primary data to achieve their objectives except Muna (2012) but it was not conducted in Nigeria. It is on this platform that the study wants to examine how investment in human resources using secondary data affect the economic sustainability of real estate industry in Nigeria.

\section{$2.3 \quad$ Hypotheses of the Study}

$\mathrm{H}_{1}$ : Human resource investment (employees' training and development cost) does not have significant effect on revenue generation.

$\mathrm{H}_{2}$ : Human resource investment (employees' training and development cost) does not have significant effect on return on asset

\section{$2.4 \quad$ Theoretical Underpinning \\ 2.4.1 Human Capital Theory}

Human capital theory was founded by Becker in 1962. Human capital theory stresses that organization resources should be developed only when investments on employee skills corresponds with the firms; productivity in the future (Bassey, 2012). This theory stresses on the value of people in organizations. According to human capital theory, people are assets to the organization and in such should be treated well with the best policies and practices that will influence their performance. Human capital theory justifies the need to highly value activities regarding management of talent.

This theory views human resource as a competitive resource that organizations can invest in and is valued by the organization since it increases productivity (Kessler \& Lülfesmann, 2006).

The relevance of this theory to the objective of the study is that if employees are adequately invested on, well managed with appropriate practices, they will be innovative and creative, readily useful and available to the organization to do the right job for all the right reasons. Thus, organization goal achievements becomes glaring and tangible.

\section{Research Methodology}

The study adopted ex-post factor research design. The population of the study comprises all 8 firms in Nigerian real estate industry that are listed in Nigerian Stock Exchange. Arbico Plc was selected because it was observed that it is the only listed firm in the real estate industry that discloses the investment (training and development cost) on the employee in the yearly reports. The study utilized secondary data and was collected from the firm's--Arbico Plc yearly reports from 2012 to 2018. Descriptive statistics and regression analysis were employed as the statistical technique through the aid of e-view statistical packages.

\subsection{Model Specification}

The study adapted the model of Muna (2012) which is expressed as 


$$
\mathrm{y}_{1}=\mathrm{f}\left(\mathrm{x}_{1}\right)
$$

Return on Investment $=\beta_{0}+\beta_{1}$ Human Resource Investment $+\mu$

Thus, the study model is therefore stated below:

$\mathrm{RG}=\beta_{0}+\beta_{1} \mathrm{HRI}_{1}+\mu_{\mathrm{i}}$

$\mathrm{ROA}=\beta_{0}+\beta_{1} \mathrm{HRI}_{1}+\mu_{\mathrm{i}}$

$\mathrm{RG}=$ Revenue Generation; ROA= Return on Asset; ROE= Return on Equity (ROE) and HRI= Human resource investment (training and development cost); $B_{0}=$ Constant; $\beta_{1}=$ the coefficient of HRI= Human resource investment; $\mu=$ the stochastic value

\section{Data Analysis, Interpretation and Discussion of Findings}

The findings of secondary data collected from Arbico annual reports from 2012 to 2018 are analysed below:

Table 1. Descriptive Statistics

\begin{tabular}{|c|c|c|c|}
\hline & LogHRI & LogRG & ROA \\
\hline Mean & 14.25582 & 21.99463 & 0.978571 \\
\hline Median & 14.70546 & 22.03635 & -0.120000 \\
\hline Maximum & 16.00358 & 22.31085 & 5.070000 \\
\hline Minimum & 10.69194 & 21.34663 & -1.270000 \\
\hline Std. Dev. & 1.662874 & 0.318214 & 2.439962 \\
\hline Skewness & -1.546796 & -1.249395 & 0.839057 \\
\hline Kurtosis & 4.345280 & 3.604226 & 2.067064 \\
\hline Jarque-Bera & 3.319191 & 1.927637 & 1.075210 \\
\hline Probability & 0.190216 & 0.381434 & 0.584146 \\
\hline Sum & 99.79071 & 153.9624 & 6.850000 \\
\hline Sum Sq. Dev. & 16.59090 & 0.607563 & 35.72049 \\
\hline Observations & 7 & 7 & 7 \\
\hline
\end{tabular}

Table 1 displayed the descriptive statistics of the variables-human resource investment (HRI) which is measured by training and development cost on the employees', revenue generation (RG), and return on asset (ROA). Human resource investment had an average log value of 14.25582 with maximum and minimum values of 16.00358 and 10.69194 respectively, with 1.662874 . The mean log value of revenue generation was 21.99463 with 22.31085 and 21.34663 as maximum and minimum values respectively as well as 0.318214 as the standard deviation. The mean of return on assets stood at 0.978571 with 5.07 and-1.27 as maximum and minimum values respectively with the standard deviation of 2.439962. The table further revealed that the data are positively skewed and the Jarque Bera statistic indicated that the test of normality was statistically insignificant as all the variables are greater than $5 \%$

\subsection{Unit Root Test}

Table 2. Unit Root Tests

\begin{tabular}{lccl} 
Variables & ADF & Unit Root@1\% @level & $1^{\text {st }}$ Difference \\
\hline HRI & -2.97 & -3.20 & Stationary \\
RG & -2.22 & -3.70 & Stationary \\
ROA & -2.89 & -3.99 & Stationary \\
\hline
\end{tabular}

Source: Researchers' Computation, 2019

Table 2 showed the unit root test of the variables. Augmented Dickey Fuller (ADF) was employed to test the stationary of the variables. Human resource investment (HRI) and revenue generation were tested at level because they were absolute values while return on asset (ROA) was tested at $1^{\text {st }}$ difference because it is not in absolute form. The results indicated that all the data for the variables are stable. For a variable to be stationary the absolute ADF statistic value should be greater than the critical values given at various percentage levels ignoring the sign.

\subsection{Test of Hypotheses}

Hypothesis One: Human resource investment (employees' training and development cost) does not have significant effect on revenue generation. 
Table 3. Human Resource Investment (HRI) and Revenue Generation (RG)

\begin{tabular}{lrlrr}
\multicolumn{1}{c}{ Variable } & Coefficient & \multicolumn{1}{c}{ Std. Error } & t-Statistic & Prob. \\
\hline \multicolumn{1}{c}{ C } & 19.43983 & 0.430329 & 45.17429 & 0.0000 \\
\multicolumn{1}{c}{ HRI } & 0.179211 & 0.030012 & 5.971377 & 0.0019 \\
R-squared & 0.877021 & Mean dependent var & 21.99463 \\
Adjusted R-squared & 0.852425 & S.D. dependent var & 0.318214 \\
S.E. of regression & 0.122244 & Akaike info criterion & -1.130646 \\
Sum squared resid & 0.074717 & Schwarz criterion & -1.146100 \\
Log likelihood & 5.957261 & Hannan-Quinn criter. & -1.321657 \\
F-statistic & 35.65735 & Durbin-Watson stat & 1.974789 \\
Prob(F-statistic) & 0.001886 & & \\
\hline
\end{tabular}

Dependent Variable: Revenue Generation

Source: Researchers' Computation, 2019

Table 3 revealed the regression results for human resource investment which was proxied by training and development cost and revenue generation. It was indicated that $87.7 \%$ of the changes in revenue generation is caused by human resource investment in Arbico Plc. It was further showed that there is positive and significant effect of human resource investment on revenue generation in the studied construction firm $(\beta=0.179, t=5.9714$, $p$-value $=.0019)$. Hence, the hypothesis is rejected

Hypothesis Two: Human resource investment (employees' training and development cost) does not have significant effect on return on asset

Table 4: Human Resource Investment (HRI) and Return on Asset (ROA)

\begin{tabular}{lrlrr}
\hline \multicolumn{1}{c}{ Variable } & Coefficient & Std. Error & t-Statistic & Prob. \\
\hline \multicolumn{1}{c}{ C } & -58.06658 & 2.205641 & -26.32640 & 0.0242 \\
\multicolumn{1}{c}{ HRI } & 4.023646 & 0.150580 & 26.72097 & 0.0238 \\
R-squared & 0.998601 & Mean dependent var & 0.863961 \\
Adjusted R-squared & 0.997203 & S.D. dependent var & 1.056422 \\
S.E. of regression & 0.055872 & Akaike info criterion & -2.696776 \\
Sum squared resid & 0.003122 & Schwarz criterion & -3.297701 \\
Log likelihood & 6.045164 & Hannan-Quinn criter. & -3.904712 \\
F-statistic & 714.0101 & Prob(F-statistic) & 0.023814 \\
\hline
\end{tabular}

Dependent Variable: Return on Asset

Source: Researchers' Computation, 2019

Table 4 displayed the regression results for human resource investment on return on asset (ROA). The table showed that $99.9 \%$ of the variations in return on asset is caused by human resource investment in Arbico Plc. It was also revealed that there is positive and significant effect of human resource investment on return on asset $(\beta=4.024, t=26.72$, $p$-value $=.0024)$. Therefore, the hypotheses is rejected

\subsection{Discussion of Findings}

The findings of the study indicated that an organization investment on the human resource enhances the income which the organization will generate. This implies that as more financial resources are committed towards training the employees, the higher the revenue that would be generated. Similarly, the more an organization spends on training the employees, the more there is increase in the return on assets which signifies that the organization asset are being effectively and fully employed in achieving organizational goals. It is evidenced that when an organization investment in their employees, it will be reflected in the degree of the organization sustainability. Economic sustainability is very essential for organization because it spells out how the organization is being sustained in terms of profitability and other financial aspects of performance. An increase in the training and development cost of a real estate firm in Nigeria will lead to increase in the return on assets of the firms. This implies that human resource investment is an element that assist in ascertaining the efficiency of the management in terms of utilization of organizational resources. In the same view, the findings has indicated that investment in human resources enhance the performance of the employees in the execution of the task assigned to them by the management effectively and efficiently. This is reflected in the revenue generation of the Arbico Plc as the human resource investment and the revenue generation move in the same direction. The more organizations in Nigerian real estate industry invest in their human resource, the more the revenue that will be generated. 


\section{Conclusions}

The study concluded that investment in human resource of the selected firm in Nigerian real estate industry influences the economic sustainability in terms of revenue generated and return on asset. Based on the findings, the study recommended that Arbico Plc should continue to invest more on training the employees and ascertain the factors that make human resource investment not to influence the firm's return on equity. Also, the regulatory authority on financial reporting in Nigeria should mandate all listed firms in the construction industry to report employee training cost in their yearly annual reports as this will enhance robust research studies relating to human resource investment in the real estate industry.

The regulatory authority on financial reporting will find the findings of the study useful as they will be enlighten if the listed firms in Nigeria are reporting what the rules expect them to report especially the firms in Nigerian real estate. Relatively, the study will serve as a platform for future on human resource investment and its related concepts.

\section{Acknowledgements}

The study does not acknowledge any individual or body. Also, the study was not funded by any individual or bosy.

\section{References}

1. Afrah, N. A. (2016). The role of human capital development on organizational performance: Case Study Benadir University, Mogadishu, Somalia. European Journal of Business and Management, 8(4) 120-124.

2. Agundu , P.U., Okwandu, G.A., \& Mba, O. (2015). Construction project management In Nigeria: Challenges and the way forward. Retreived from www. Researchnet.Com

3. Ajisafe, R.A., Orifa, R.A., \& Balogun, J.A. (2015). Influence of human capital management on organisational performance. Journal of Resource, 1, 1-9

4. Aniekwu N. C. Igboanugo A., \& Onifade, M.K. (2015). Critical issues in reforming the Nigerian construction industry. British Journal of Applied Science \& Technology, 5(3), 321-332

5. Baron, A. (2011). Measuring human capital.Strategic Human Resources Review, 10(2), 30-35.

6. Bassey, B.E. (2012). Expensed human resources cost and its influence on corporate productivity: A study of selected companies in Nigeria. Global Journal of Management and Business Research, 12(5), 3-8

7. Becker, G. (1964). Human capital. A theoretical and empirical analysis with special reference to education. Chicago and London: The University of Chicago Press.

8. Bontis, N. (2001). Assessing knowledge assets: A review of the models used to measure intellectual capita. International Journal of Managerial Research, 1, 2-17

9. Boxall A. (1996). Managing human resources. Cincinnati: South-western College

10. Cho, S., Chung, C.Y., \& Young, J. (2019). Study on the relationship between corporate social responsibility and financial performance, Sustainability, 1, 11, 343

11. Dabale, W.P., Jagero, J., \& Nyauchi, M. (2014). The relationship between training and employee performance: The case of Mutare City Council, Zimbabwe. International Journal of Human Resource Studies, 4(4), 61-73

12. Dadashinasab, M., \& Sofian, S. (2014). The impact of intellectual capital on firm financial performance by moderating of dynamic capability. Asian Social Science, 10(17), 99-110

13. Dawodu, A. A., Akintunde, O. A., \& Olulana, B. S. (2018). Human capital development and organizational performance in the food, beverage and tobacco industry in Lagos State. Nigeria. Nigerian Journal of Management Studies, 18(2), 27-35

14. Ekundayo, O. U., \& Odhigu, F. (2016). Determinants of human capital accounting in Nigeria. Igbinedion University Journal of Accounting, 1, 103-117

15. Epps, R. W., \& Cereola, S. J. (2008). Do institutional shareholder services (ISS) corporate governance ratings reflect a company's operating performance? Critical Perspectives on Accounting, 19(1), 1138-1148.

16. Fawowe, D. (2018). Human resource management practices and employee performance in pharmaceutical industry in Nigeria. M.Sc Thesis, Babcock University, Nigeria

17. Fayemi, H. (2001). Evolution of state government in Nigeria, Journal of Nigerian Public Administration and Management, 2(2), 72-91

18. Hashima, M.J., Osmanb, I., \&Alhabshic , S.M. (2015). Effect of intellectual capital on organizational performance.Procedi -Social and Behavioral Sciences, 2(11), 207-214

19. Hines, R. (2000). Popper's methodology of falsification and accounting research. The Accounting Review, 63(4), 657-662.

20. Iheme, C.C., \& Chiagorom, C.F. (2018). Construction Industry and its Constraints in Nigeria. International Journal of Advanced Research in Social Engineering and Development Strategies, 5(1), 44-53

21. Kessler, A. S., \& Lülfesmann, C. (2006). The theory of human capital revisited: On the interaction of general and specific investments. Economic Journal, 116(514), 903-923.

22. Mba, O.A., \& Tonye, O. (2015). Human resource development and organisational performance in Nigerian Liquefied Natural Gas Company Limited, Bonny. Journal of Management and Sustainability, 4(4), 134-146.

23. Muna, A. (2012). The impact of investments in human resources activities on the effectiveness of investment in human capital: The case of commercial banks in Jordan. International Journal of Business and Social Science, 3(18), 253-261

24. Ochieng, P.A. (2016). Relationship between talent management practices and employee retention at DHL supply chain Kenya limited. M.Sc Thesis Submitted to the School of Business. University of Nairobi

25. Ojokuku, R.M., \& Sajuyigbe, A.S. (2015). Effect of human capital development on the performance of small and medium scale enterprises in Nigeria. Journal of Emerging Trends in Economics and Management Sciences, 6(1) 88-93.

26. Okunbanjo, O.I. (2016). Leadership style, employee empowerment and organizational performance in Nigerian banking industry. M.Sc Thesis, Lagos State University, Ojo

27. Olajide, O.T \&Okunbanjo, O.I. (2018). Leadership style, employee empowerment and organizational performance in Nigerian banking industry.BVIMSR Journal of Management Research, 10(2), 135-142

28. Olajide, O.T. (2019). Intellectual capital and organizational performance in Nigerian insurance industry. A Paper Presented at Faculty of Management Science, Lagos State University Annual Conference

29. Olajide, R.A. (2015). Revenue generation as a major source of income for the state government: An empirical analysis of two parastatals. International Journal of Economics, Commerce and Management, 3(6), 1346-1366 
30. Onwumelu O.P., \& Dialoke, I. (2018). Impact of human capital development on employee performance: A study of selected oil service firms in Rivers State, Nigeria. International Journal of Social Sciences and Management Research, 4(3), 56-69

31. Onyango, J.W., \& Wanyoike, D.M. (2014). Effects of training on employee performance: a survey of health workers in Siaya County, Kenya. European Journal of Material Sciences, 1(1), 11-15

32. Sampson, C. J., Ibeh G.O. \& Emerole G.A (2016). Effect of human capital development programmes in optimizing employees performance: A study of Abia State house of assembly, Ngeria. Singaporean Journal of business Economics and Management, 5(4), 1-12

33. Sowunmi, S. O., Eleyowo, I. O., Salako, M. A., \& Oketokun, F. O. (2015). Human resource development as a correlate of performance of the banking industry in Ogun State, Nigeria, Journal of Economics and International Finance, 7(5), 112-126.

34. Tarus, D., \& Sitienei, E. (2015). Intellectual capital and innovativeness in software development firms: The moderating role of firm size. Journal of African Business, 16, 48-65.

35. Tunji - Olayeni, P.F., Lawal, P.O., \& Amusan, L.M. (2012). Developing infrastructure in Nigeria: why is the cost so high? Mediterranean Journal of Social Sciences, 2(3), 262-270

36. Tunji-Olayeni, P.F., Mosaku, T.O., Fagbenle, O.I. \& Omuh, I.O. (2017). Competitive strategies of indigenous construction firms. International Journal of Civil Engineering and Technology, 8(10), 350-362

37. Ussahawanitchakit, P. (2017). Management control systems and firm sustainability: evidence from textile and apparel businesses in Thailand. Asian Academy of Management Journal, 22(2), 185-208

38. Wan, N. Abdullah, A., \& Mohamed, D.I (2018). The economic sustainability of small business: An empirical analysis on the mobile phone banking in Dhaka City. International Journal of Sustainable Strategic Management, 5(5), 231-245

39. Zahan, M., \& Sultana, H. (2019). Sustainable mission statement of international firms: An empirical study. The Jahangirnagar University Journal of Business Research, 20, 37-51 